\title{
PENGARUH MOTIVASI DAN LINGKUNGAN KERJA TERHADAP KINERJA KARYAWAN PADA PT. TRIVIEW GEOSPATIAL MANDIRI JAKARTA SELATAN
}

\author{
Bunga Astra Gracia ${ }^{1)}$
}

1) dosen universitas pamulang, email : astra bunga@yahoo.com

\section{ARTICLES}

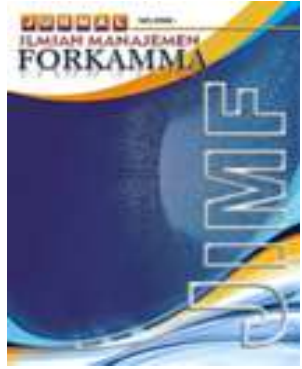

\section{JURNAL ILMIAH MANAJEMEN FORKAMMA}

\author{
Vol.2, No.2, Maret 2019 \\ Halaman : $31-48$ \\ (c) LPPM \& FORKAMMA
}

Prodi Magister Manajemen UNVERSITAS PAMULANG

$$
\begin{array}{ll}
\text { ISSN (online) } & : 2599-171 X \\
\text { ISSN (print) } & : 2598-9545
\end{array}
$$

\section{Keyword :}

Motivation. Work Enviroment. Performances

\section{JEL. classification :}

O15,

Contact Author :

$$
\begin{gathered}
\text { PRODI } \\
\text { MAGISTER MANAJEMEN \& } \\
\text { FORKAMMA UNPAM } \\
\text { JL.Surya Kencana No.1 Pamulang } \\
\text { Tangerang Selatan - Banten } \\
\text { Telp. (021) 7412566, aax (021) } 7412491 \\
\text { Email : } \\
\text { jurnalforkamma.unpam@gmail.com }
\end{gathered}
$$

Tujuan penelitian ini untuk mengetahui seberapa besar pengaruh Motivasi dan lingkungan Kerja terhadap Kinerja Karyawan pada PT. Triview Geospatial Mandiri, Jakarta Selatan. Jenis penelitian merupakan penelitian kuantitatif dianalisis menggunakan statistik penulis dengan karyawan PT. Triview Geospatial Mandiri sebagai obyek penelitian. Adapun jumlah sampel diperoleh teknik sampling jenuh sebanyak 35 responden. Analisis data menggunakan SPSS Versi 21. Teknik Analisa data diantaranya uji validitas, uji reliabilitas, uji asumsi klasik dan uji regresi linear berganda serta uji hipotesis. Hasil penelitian menunjukan bahwa Motivasi memiliki pengaruh sebesar 33,2\% terhadap Kinerja dan Lingkungan Kerja memiliki pengaruh sebesar $20,1 \%$ sedang pengaruh secara simultan motivasi dan lingkungan kerja terhadap kinerja karyawan sebesar $38 \%$

The purpose of this research is to determine how much influence of Motivation and work enviroment toward performances on the PT. Triview Geospatial Mandiri, South Jakarta. This type of research is quantitative research were analyzed using statistics, with the employee of PT. Triview Geospatila Mandiri as the researches object. As for the number of samples obtained from census method as many as 35 respondents. Data analysis using SPSS Version 21. Analysis data techniques include validity test, reliability test, classical assumption test and multiple linear regression test and test the hypothesis. The results of the study showed that motivation has the effect of $33,2 \%$ of performances and work enviroment have an influence similar to $20,1 \%$ for the simultaneous influence of motivation and work enviroment towards Employee performasnces by $38 \%$ 


\section{A. Pendahuluan}

Perusahaan dapat berkembang merupakan keinginan setiap individu yang berada di dalam instansi tersebut, sehingga diharapkan dengan perkembangan tersebut instansi mampu bersaing dan mengikuti kemajuan zaman. Karena itu, tujuan yang diharapkan oleh instansi dapat tercapai dengan baik. Kemajuan instansi dipengaruhi oleh faktor-faktor lingkungan yang bersifat internal dan eksternal. Sejauh mana tujuan instansi telah tercapai dapat dilihat dari seberapa besar instansi memenuhi tuntutan lingkungannya. Memenuhi tuntutan lingkungan berarti dapat memanfaatkan kesempatan atau mengatasi tantangan lingkungan atau ancaman dari lingkungan dalam rangka menghadapi atau memenuhi tuntutan dan perubahan-perubahan di lingkungan instansi.

Performance atau yang lebih dikenal dengan kinerja adalah hasil kerja yang dapat di capai oleh seseorang atau sekelompok orang dalam suatu organisasi, sesuai dengan wewenang dan tanggungjawab masing-masing, dalam rangka upaya mencapai tujuan organisasi bersangkutan secara legal, tidak melanggar hukum dan sesuai dengan moral maupun etika. Kinerja dapat diartikan sebagai gambaran mengenai tingkat pencapaian pelaksanaan suatu kegiatan atau program atau kebijakan dalam mewujudkan sasaran, tujuan, misi dan visi organisasi yang tertuang dalam rencana strategi suatu organisasi. Istilah kinerja sering digunakan untuk menyebut prestasi atau tingkat keberhasilan individu atau kelompok individu. Kinerja dapat diketahui hanya jika individu atau kelompok individu tersebut memiliki kriteria keberhasilan yang telah ditetapkan. Kriteria keberhasilan ini berupa tujuan-tujuan atau target-target tertentu yang hendak dicapai. Tanpa adanya tujuan serta target, kinerja seseorang atau organisasi tidak dapat diketahui karena tidak ada tolok ukurnya

Motivasi kerja merupakan hal penting dalam pencapaian kinerja karena bersifat dinamis dalam meningkatkan efektifitas kerja, karena orang yang memiliki motivasi kerja yang tinggi akan berusaha sekuat tenaga agar pekerjaannya dapat berhasil dengan sebaik-baiknya. Menurut Menurut Hasibuan Malayu S.P dalam Sunyoto Danang (2012:191) motivasi adalah suatu perangsang keinginan daya gerak kemauan bekerja seseorang, setiap motif mempunyai tujuan tertentu yang ingin dicapai.

Menurut Sedarmayati (2017:26) mendefinisikan bahwa Lingkungan kerja adalah semua keadaan yang terdapat disekitar tempat kerja, akan mempengaruhi pegawai baik secara langsung maupun secara tidak langsung. Karyawan akan mampu melaksanakan kegiatannya dengan baik, sehingga dicapai suatu hasil yang optimal, apabila diantaranya ditunjang oleh suatu kondisi lingkungan yang sesuai. Dengan memperhatikan lingkungan kerja yang baik atau menciptakan kondisi kerja yang mampu memberikan motivasi untuk bekerja maka akan membawa pengaruh terhadap kegairahan atau semangat karyawan untuk bekerja.

Menurut Malayu Hasibuan (2011:94) kinerja karyawan adalah "hasil kerja yang dicapai seseorang dalam melaksanakan tugas-tugas yang dibebakan kepadanya yang didasarkanatas kecakapan, pengalaman, dan kesungguhan serta waktu". Kinerja merupakan gabungan dari tiga faktor penting yaitu kemampuan dan minat seorang pekerja, kemampuan dan penerimaan atas penjelasan delegasi tugas serta peran dan tingkat motivasi seorang pekerja.

PT. Triview Geospatial Mandiri merupakan perusahaan yang bergerak di bidang Penyedia Tower / Tower Provider (TP) yang membangun Tower Telekomunikasi dan atau Infrastruktur Telekomunikasi lainnya di seluruh Indonesia sejak tahun 2003. Manajemen PT. Triview Geospatial Mandiri sangat mengharapkan setiap karyawannya dapat menciptakan disiplin yang tinggi demi kemajuan perusahaan dan pencapaian tujuan perusahaan yang efektif dan efisien.

Hasil Survey awal di PT. Triview Geospatial Mandiri diketahui bahwa motivasi kerja karyawan mengalami penurunan sehingga menyebabkan kinerja karyawan 
semakin menurun. Semangat kerja karyawan dalam melakukan pekerjaannya mengalami penurunan hal ini dapat dilihat dari banyak karyawan yang mulai malasmalasan, telat masuk kerja, sering alfa (tidak masuk tanpa keterangan).

Tabel 1.1

Data Absensi Karyawan PT. Triview Geospatial Mandiri

Periode September - November 2017

\begin{tabular}{|c|c|c|c|c|}
\hline Bulan & Sakit & Izin & Telat & Alfa \\
\hline September & 3 & 3 & 4 & 4 \\
\hline Oktober & 4 & 3 & 3 & 4 \\
\hline November & 5 & 4 & 6 & 5 \\
\hline
\end{tabular}

Sumber : PT. Triview Geospatial Mandiri ( 2017 )

Dari tabel 1.1 diatas, diketahui bahwa karyawan yang alpa di bulan September sebanyak 4 orang, di bulan Oktober sebanyak 4 orang dan di bulan November sebanyak 5 orang. Untuk karyawan yang Telat di bulan September sebanyak 4 orang, di bulan Oktober sebanyak 3 orang dan di bulan November sebanyak 6 orang. Dikarenakan banyak karyawan yang alpa, izin dan telat sehingga banyak pekerjaan yang tertunda, tidak selesai tepat pada waktunya, rasa tanggung jawab karyawan terhadap pekerjaannya juga berkurang. Sanksi sudah diberikan bagi karyawan yang sering telat atau alfa, seperti pemotongan gaji atau jatah cuti, akan tetapi hal ini dinilai masih kurang efektif karena tidak menimbulkan efek jera.

Motivasi kerja karyawan sangat berkaitan dengan kebutuhan dari karyawan. Dalam memenuhi kebutuhan kehidupannya sehari-hari, gaji yang diterima karyawan dirasakan masih kurang sehingga akhirnya dorongan untuk mencapai target pekerjaan berkurang. Selain itu banyak karyawan yang melaksanakan pekerjaan yang diluar jobdesc atau bahkan double job, akan tetapi hal ini tidak diikuti dengan kenaikan gaji. Sehingga akhirnya banyak karyawan yang merasa tidak adil, mulai malas-malasan, memanfaatkan waktu jam kerja dengan main gadget, belanja online, mengobrol dengan teman kerjanya. Promosi jabatan dan penghargaan juga tidak dirasakan oleh karyawan. Banyak karyawan yang memegang jabatan yang sama setelah bekerja lebih dari 5 tahun. Inisiatif dan kreatifitas karyawan ketika mengalami kendala dirasakan kurang, sehingga butuh pengawasan terus menerus dari pimpinan. Karyawan juga tidak diberikan kesempatan untuk mengutarakan pendapatnya atau berkembang, sehingga akhirnya banyak karyawan yang kemampuan tidak berkembang, bersikap apatis, acuh tak acuh.

Faktor lain dalam meningkatkan kinerja yang tidak kalah penting yaitu lingkungan kerja. Untuk mencapai kinerja karyawan yang baik, perusahaan harus dapat mengkondisikan bagaimana dan seperti apa lingkungan kerja yang cocok dan nyaman bagi para karyawan, terpenuhinya perlengkapan yang dibutuhkan oleh karyawan serta terjalinnya hubungan yang baik antar sesama rekan kerja, bawahan dan atasan. Dalam prakteknya dilapangan, fasilitas kerja yang ada dirasakan masih kurang, hal ini dapat dilihat dari data fasilitas kerja sebagai berikut :

Tabel 1.2

Data Fasilitas Kantor PT.Securindo Packatama Indonesia

\begin{tabular}{|l|l|l|}
\hline \multicolumn{1}{|c|}{ Aset } & Jumlah & \multicolumn{1}{c|}{ Keterangan } \\
\hline $\mathrm{AC}$ & 17 buah & 7 rusak \\
\hline Printer & 3 buah & 1 Rusak \\
\hline Komputer & 15 buah & Kondisi Baik \\
\hline
\end{tabular}




\begin{tabular}{|l|c|c|}
\hline Meja & 35 buah & 6 meja besar, 29 meja sedang \\
\hline Kursi & 60 buah & 5 rusak \\
\hline Jumlah & $:$ 13 Aset yang harus di perbaiki \\
\hline
\end{tabular}

\section{Sumber : PT. Triview Geospatial Mandiri (2017)}

Dari data tabel 1.2 diatas, diketahui bahwa Komputer terdapat 15 unit dimana hal ini dirasakan masih kurang mengingat jumlah karyawan 35 orang, akhirnya banyak dari karyawan yang menggunakan laptop pribadi untuk melakukan pekerjaannya. Printer tersedia 3 unit dimana tiap 1 lantai disediakan 1 printer, tapi hal inipun dirasakan kurang karena ada 1 yang rusak. Untuk mencetak hasil pekerjaannya, karyawan harus bergiliran dan terkadang persediaan tinta tidak pernah stock sehingga apabila tinta habis, karyawan harus mencetak diluar kantor. Fasilitas Alat Kerja Kantor (ATK) disediakan oleh kantor, tapi tidak dikontrol sehingga apabila habis, terkadang karyawan harus membeli sendiri dengan biaya sendiri.

Tingkat kebisingan di lingkungan kerja relatif cukup atau tidak terlalu bising, sedangkan penerangan didalam kantor dirasakan cukup walaupun terkadang lampu yang ada suka rusak sehingga harus sering diganti. Unit AC yang ada dirasakan masih kurang, karena masih ada beberapa ruangan yang AC nya rusak sehingga suhu udara meningkat, sirkulasi udara juga tidak berjalan lancar.

Hubungan antar karyawan dirasakan kurang erat sehingga kerjasama antar karyawan dirasakan kurang. Hubungan antar atasan dan bawahan juga dirasakan kurang dierat dikarenakan sedang masa transisi pergantian pimpinan. Karyawan merasa pimpinan kurang pengawasan, kurang memiliki wibawa dan terkesan pilih kasih (tidak adil). Selain itu keamanan dirasakan masih kurang aman dikarenakan pernah terjadi kasus kehilangan handphone sehingga tingkat keamanan perlu ditingkatkan.

Dikarenakan Motivasi Kerja karyawan menurun dan lingkungan kerja yang kurang kondusif, membuat kinerja karyawan mengalami penurunan. Dari hasil pengamatan dilapangan, kinerja karyawan mengalami penurunan. Hal ini dapat dilihat dari tabel dibawah ini :

Tabel 1.3

Data Target Pekerjaan Karyawan PT. Triview Geospatial Mandiri

\begin{tabular}{|c|c|c|c|c|c|c|}
\hline \multirow{2}{*}{ Bulan } & \multicolumn{6}{|c|}{ PEKERJAAN } \\
\cline { 2 - 7 } & \multicolumn{2}{|c|}{ SITAC } & \multicolumn{2}{c|}{ RFC } & \multicolumn{2}{c|}{ CME } \\
\cline { 2 - 7 } & Jumlah & Target & Jumlah & Target & Jumlah & Target \\
\hline September & 62 & 95 & 55 & 80 & 69 & 75 \\
\hline Oktober & 41 & 95 & 34 & 80 & 44 & 75 \\
\hline November & 33 & 95 & 21 & 80 & 30 & 75 \\
\hline
\end{tabular}

Sumber : PT. Triview Geospatial Mandiri ( 2017 )

Dari Tabel 1.3 dapat diketahui bahwa pencapaian target pekerjaan karyawan semakin menurun dari bulan September sampai Bulan November. Hal ini bisa dilihat dari pekerjaan RFC dibulan September target 80 tapi yang dapat diselesaikan hanya 55. Di Bulan Oktober dan November juga begitu. Hal ini juga terlihat di pekerjaan RFC, CME dimana jumlah pekerjaan yang harus diselesaikan tidak dapat memenuhi target. Selain itu ada beberapa karyawan yang dalam mengerjakan pekerjaannya tidak teliti, terkadang suka menunda-nunda pekerjaan, kerjasama antar karyawan juga kurang. Hal ini menyebabkan mutu kerja karyawan menurun.

Kualitas kerja karyawan menurun dimana masih banyak ditemukan karyawan yang kurang cepat tanggap, jumlah pekerjaan yang harus diselesaikan terus 
bertambah. Dari hasil pengamatan dilapangan, banyak karyawan yang melaksanakan pekerjaan yang diluar jobdesc atau bahkan double job, karena overload akhirnya mereka mengerjakannya tidak sepenuh hati. Semangat dan ketangguhan karyawan juga menurun, dilihat dari masih banyak karyawan yang datang terlambat, sering alfa (ijin tanpa keterangan), sehingga banyak pekerjaan yang tidak terselesaikan tepat waktu. Walaupun sudah diberikan sanksi bagi karyawan yang melanggar peraturan, namun dirasakan kurang memberikan efek jera. Sikap karyawan terhadap pekerjaannya menunjukkan rasa tanggungjawab yang kurang, kerjasama antara karyawan dan team work dirasakan kurang sehingga terkadang mereka lebih suka menyelesaikan pekerjaannya sendiri. Hubungan karyawan dengan atasanpun kurang erat, pimpinan jarang melakukan pengawasan terhadap hasil kerja karyawan. Karena pengawasan yang kurang sehingga karyawan dalam melakukan pekerjaannya terkesan asal-asalan.

Berdasarkan uraian latar belakang yang telah disajikan diatas, dimana lingkungan kerja dan motivasi kerja mempengaruhi kinerja karyawan, maka penulis tertarik untuk melakukan penelitian dengan judul penelitian "PENGARUH MOTIVASI DAN LINGKUNGAN KERJA TERHADAP KINERJA KARYAWAN PADA PT. TRIVIEW GEOSPATIAL MANDIRI".

\section{B. Perumusan Masalah}

Berdasarkan latar belakang yang telah diungkapkan di atas, maka rumusan masalah dalam penelitian ini adalah:

1. Bagaimana pengaruh Motivasi terhadap Kinerja Karyawan pada PT. Triview Geospatial Mandiri?

2. Bagaimana pengaruh Lingkungan kerja terhadap kinerja karyawan pada PT. Triview Geospatial Mandiri?

3. Seberapa besar pengaruh Motivasi dan Lingkungan Kerja terhadap kinerja karyawan pada PT. Triview Geospatial Mandiri?

\section{Tujuan Penelitian}

1. Untuk mengetahui bagaimana pengaruh motivasi kerja terhadap kinerja karyawan pada PT. Triview Geospatial Mandiri.

2. Untuk mengetahui bagaimana pengaruh Lingkungan kerja terhadap kinerja karyawan pada PT. Triview Geospatial Mandiri.

3. Untuk mengetahui seberapa besar pengaruh Motivasi dan Lingkungan Kerja terhadap kinerja karyawan pada PT. Triview Geospatial Mandiri.

\section{Hipotesis Penelitian dan Kerangka Berpikir}

Hipotesis dalam penelitian ini adalah sebagai berikut:

$\mathrm{H}_{1}$ : Diduga terdapat pengaruh yang positif dan signifikan dari Motivasi terhadap Kinerja karyawan.

H2 : Diduga terdapat pengaruh yang positif dan signifikan dari Lingkungan kerja terhadap Kinerja karyawan

H3 : Diduga terdapat pengaruh yang positif dan signifikan secara simultan dari Motivasi dan Lingkungan Kerja terhadap Kinerja karyawan

Sedangkan kerangka berfikir untuk penelitian ini dapat digambarkan sebagai berikut: 
PENGARUH MOTIVASI \& LINGKUNGAN KERJA TERHADAP KINERJA KARYAWAN PADA PT. TRIVIEW GEOSPATIAL MANDIRI

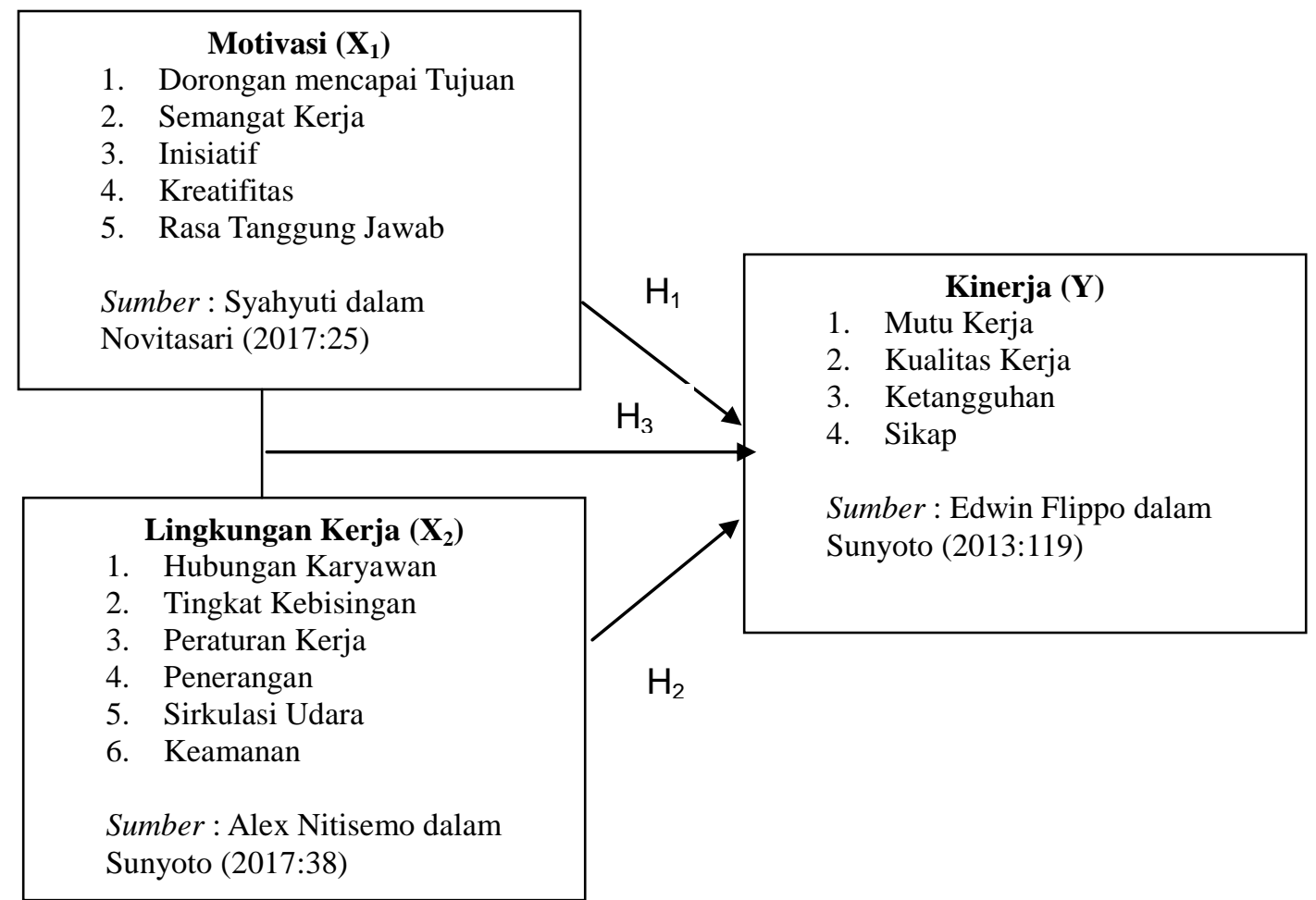

Gambar. 1.1

Kerangka Berpikir

\section{E. Landasan Teori \\ Manajemen}

Menurut Wibowo (2013:2) Manajemen adalah proses penggunaan sumber daya organisasi dengan menggunakan orang lain mencapai tujuan organisasi secara efisien dan efektif. Sedangkan Nickels, Mc. Hugh dann Mc. Hugh yang dikutip oleh Suhardi (2018:23) menyatakan manajemen sebagai proeses yang dilakukan untuk mewujudkan tujuan organisasi melalui rangkaiankegiatan berupa perencanaan, pengorganisasian, pengarahan dan pengendalian orang-orang serta sumber daya organisasi lainnya.

\section{Manajemen Sumber Daya Manusia}

Simamora dalam Sutrisno (2017:5) mengemukakan manajemen sumber daya manusia adalah pendayagunaan, pengembangan, penilaian, pemberian balas jasa dan pengelolaan individu anggota organisasi atau kelompok pekerja. Marihot Tua E.H dalam Sunyoto (2013:1) menndefinisikan "Human resource management is the activites undertaken to attact, develop, motivate, and maintain a high performing workface within the organization" (Manajemen sumber daya manusia adalah aktivitas yang dilakukan merangsang, mengembangkan, memotivasi dan memelihara kinerja yang tinggi dalam organisasi). Menurut Danang Sunyoto (2017:4) fungsi-fungsi Manajemen Sumber Daya Manusia, meliputi : Fungsi Manajerial dan fungsi Operasional. 


\section{Motivasi}

Istilah motivasi (motivation) berasal dari bahasa latin, yaitu 'movere'yang artinya mendorong atau menggerakkan (to move). Gray dalam Hamali (2017:130) mendefinisikan motivasi sebagai hasil sejumlah proses yang bersifat internal atau eksternal bagi seorang individu, yang menyebabkan timbulnya sikap antusiasme dan persistence dalam hal melaksanakan kegiatan-kegiatan tertentu. Seseorang yang termotivasi yaitu orang yang melaksanakan upaya substansial guna menunjang tujuan-tujuan produksi kesatuan kerjanya dan organisasi tempat seseorang bekerja. Menurut Saydam dikutip oleh Kadarisman (2014:275) motivasi dalam kehidupan sehari-hari diartikan sebagai keseluruhan proses pemberian dorongan atau rangsangan kepada para karyawan sehingga mereka bersedia bekerja dengan rela tanpa dipaksa. Organisasi akan berhasil melaksanakan program-programnya bila orang-orang yang bekerja dalam organisasi dapat melaknakan tugasnya dengan baik sesuai bidang dan tanggung jawabnya masing-masing. Jadi motivasi merupakan dorongan yang dapat membangkitkan kemauan kerja karyawan untuk memulai melaksanakan pekerjaan sesuai tugas dan tanggung jawabnya Tanpa adanya motivasi dari para karyawan untuk bekerjasama bagi kepentingan perusahaan, maka tujuan yang telah ditetapkan tidak akan tercapai

\section{Lingkungan Kerja}

Lingkungan kerja fisik yang sangat baik sangat diperlukan oleh setiap karyawan pada saat bekerja. Untuk meningkatkan kenyamanan dan loyalitas para pekerja karena apabila para karyawan bekerja dengan sangat ikhlas dan semangat sangatlah mungkin jalannya operasional perusahaan akan berjalan dengan baik dan mencapai tujuan perusahaan. Menurut Danang Sunyoto (2017:388), lingkungan kerja merupakan bagian komponen yang sangat penting ketika karyawan melakukan aktivitas bekerja. Sedangkan Alex Nitisemito dalam Sunyoto (2017:38) mengemukakan lingkungan kerja adalah segala sesuatu yang ada di sekitar para pekerja dan yang dapat memengaruhi dirinya dalam menjalankan tugas-tugas yang dibebankan, misalnya kebersihan, musik, penerangan dan lain-lain. Dengan memperhatikan lingkungan kerja yang baik atau menciptakan kondisi kerja yang mampu memberikan motivasi untuk bekerja maka akan membawa pengaruh terhadap kegairahan atau semangat karyawan untuk bekerja.

\section{KInerja}

Kinerja berasal dari kata job performance atau actual performance yang berarti prestasi kerja atau prestasi sesungguhnya yang dicapai oleh seseorang.Pengertian kinerja (prestasi kerja) adalah hasil kerja secara kualitas dan kuantitas yang dicapai oleh seorang pegawai dalam melaksanakan fungsinya sesuai dengan tanggung jawab yang diberikan kepadanya. Menurut Heidjrachman, Suad Hasan dalam Sunyoto (2017:17) "Prestasi Kerja adalah sesuatu hasil kerja yang dicapai seseorang dalam melaksanakan menyelesaikan pekerjaan yang dibebankan kepadanya". Prof. Dr. H. Edy Sutrisno (2017:151) menyatakan "kinerja adalah sebagai hasil kerja yang telah dicapai seseorang dari tingkah laku kerjanya dalam melaksanakan aktivitas kerja". Karyawan yang menunjukkan kinerja yang tinggi memiliki keinginan untuk memberikan tenaga dan tanggung jawab yang lebih dalam meraih kesejahteraan dan keberhasilan perusahaan tempat nya bekerja. Kinerja pada dasarnya adalah apa yang dilakukan karyawan sehingga mempengaruhi banyaknya kontribusi yang diberikan kepada perusahaan termasuk pelayanan yang berkualitas yang disajikan. Kesuksesan dari perusahaan bisa dilihat dari pekerjaan yang telah dicapai oleh karyawan, karena itu perusahaan menuntut agar para karyawannya mampu menampilkan kinerja yang optimal. Untuk itu, kinerja karyawan harus mendapatkan 
perhatian dari para pemimpin perusahaan, sebab menurunnya kinerja karyawan dapat mempengaruhi menurunnya kinerja perusahaan secara keseluruhan.

\section{F. Metodologi Penelitian}

Pada penelitian ini peneliti melakukan penelitian atau riset data pada PT.Triview Geospatial Mandiri yang beralamat di Komplek Perkantoran Duta Mas Fatmawati Blok B1 No.17-18, Jalan RS Fatmawati kelurahan Cipete Utara kecamatan Kebayoran Baru Kota Jakarta Selatan. Obyek yang diteliti adalah Karyawan yang bekerja di PT. Triview Geospatial Mandiri. Waktu penelitian dilaksanakan pada bulan April 2018 sampai dengan Juni 2018. Penelitian ini dilakukan untuk mengetahui pengaruh Motivasi dan Lingkungan Kerja terhadap Kinerja Karyawan.

Penulis menggunakan metode penelitian diskriptif dengan pendekatan kuantitatif. Menurut Sugiyono (2011: 7), metode kuantitatif dinamakan metode tradisional, karena metode ini sudah cukup lama digunakan sehingga sudah mentradisi sebagai metode untuk penelitian. Dinamakan metode kuantitatif karena data dalam penelitian ini menggunakan angka-angka dan analisis menggunakan statistik.

\section{Populasi Dan Sampel}

a. Populasi

Menurut Sugiyono (2011: 80), populasi adalah wilayah generalisasi yang terdiri atas objek atau subjek yang mempunyai kualitas dan karakteristik tertentu yang ditetapkan oleh penelitian untuk dipelajari dan kemudian ditarik kesimpulannya. Adapun Populasi dalam penelitian ini sebanyak 35 orang pada PT. Triview Geospatial Mandiri

b. Sampel

Menurut Sugiyono (2011:81), sampel adalah bagian dari jumlah dan karakteristik yang dimiliki oleh populasi tersebut. Teknik pengambilan sampel pada penelitian ini adalah teknik Nonprobability Sampling dengan cara Sampling Jenuh. Lebih lanjut Menurut Sugiyono (2011:84), Nonprobability Sampling adalah teknik pengambilan sampel yang tidak memberi peluang / kesempatan sama bagi setiap unsur atau anggota populasi untuk dipilih menjadi sampel. Teknik sampel ini meliputi sampling sistematis, kuota, aksidental, purposive, jenuh, dan snowball.

Sampling jenuh adalah teknik penentuan sampel bila semua anggota populasi digunakan sebagai sampel.Hal ini sering dilakukan bila jumlah populasi relatif kecil, kurang dari 30 orang atau penelitian yang ingin membuat generalisasi dengan kesalahan yang sangat kecil. Istilah lain sampel jenuh adalah sensus, dimana semua anggota populasi dijadikan sampel (Sugiyono, 2011:85). Maka Jumlah sampel untuk penelitian ini adalah 35 responden.

\section{G. Analisis Data}

Analisis data yang digunakan dalam penelitian ini adalah uji validitas dan uji reliabilitas. Pengujian validitas menggunakan rumus korelasi pearson product moment, dengan ketentuan jika $r_{\text {hitung }}>r_{\text {tabel }}$, berarti instrumen valid. Pengujian reliabilitas dalam penelitian ini menggunakan nilai Alpha Cronbach dengan ketentuan jika Alpha Cronbach $\left(r_{\text {hitung }}\right)>0,60$ berarti instrumen tersebut reliabel. Teknik analisis data antara lain uji asumsi klasik dan analisis regresi ganda. Uji asumsi klasik terdiri dari uji normalitas, uji multikolinearitas, uji autokorelasi.

\section{Uji Asumsi Klasik}

\section{a. Uji Normalitas}

Data yang telah terkumpul harus diuji normalitasnya terlebih dahulu guna mengetahui apakah data penelitian berasal dari populasi yang 
sebarannya normal atau tidak. Pengujian normalitas menggunakan Onesample Kolmogorov-Smirnov Test dengan SPSS 21.0 for windows. Dengan ketentuan, jika nilai Asymp Sig > 0,05 maka data berdistribusi normal.

\section{b. Uji Multikolinearitas}

Uji Multikolinearitas dilakukan untuk mengetahui ada tidaknya kemiripan yang dimiliki oleh satu variabel independent dengan variabel independen yang lain dalam satu model. Pengujian multikolinearitas dalam penelitian ini menngunakan VIF (Variance Inflation Factor), dengan ketentuan jika nilai tolerance $>0,1$ dan nilai $\mathrm{VIF}<10$, maka data tidak maka data tidak mengalami multikolinearitas.

\section{c. Uji Autokorelasi}

Uji Autokorelasi dilakukan untuk mengetahui adakah korelasi variabel yang ada di dalam model prediksi dengan perubahan waktu. Oleh karena itu, apabila asumsi autokorelasi terjadi pada sebuah model prediksi, maka nilai disturbance tidak lagi berpasangan secara bebas, melainkan berpasangan secara autokorelasi. Pengujian autokorelasi dalam penelitian ini menggunakan analisis Uji Durbin Watson yang akan menghasilkan nilai Durbin Watson (DW) yang nantinya akan dibandingkan dengan dua (2) nilai Durbin Watson Tabel, yaitu Durbin Upper (DU) dan Durbin Lower DL). Dikatakan tidak terdapat autokorelasi jika nilai DW $>$ DU dan (4-DW) $>$ DU atau bisa dinotasikan juga sebagai berikut: $(4-D W)>D U<D W$.

\section{Analisis Regresi Ganda}

Teknik analisis regresi ganda dipergunakan untuk mengetahui pengaruh Motivasi dan Lingkungan Kerja terhadap Kinerja Karyawan PT. Triview Geospatial Mandiri. Dengan persamaan regresi $Y=a+b_{1} X_{1}+X_{2} b_{2}+X_{3} b_{3}$.

Teknik pengujian hipotesis menggunakan uji parsial (Uji t) dan uji simultan (Uji F) dengan teknik probabilitas, dengan cara membandingkan nilai probabilitas Sig dengan taraf signifikansi 0,05. Jika nilai probabilitas sig $<0,05$ maka signifikan.

\section{Koefisien Determinasi}

Pengujian koefisien determinasi bertujuan untuk mengetahui besarnya pengaruh antar variabel. Nilai koefisien determinasi menunjukkan presentase variasi nilai variabel dependen yang dapat dijelaskan oleh persamaan regresi yang dihasilkan.

\section{H. Hasil Analisis Deskriptif}

1. Deskripsi Motivasi Kerja

\begin{tabular}{|l|l|c|c|c|c|c|c|c|c|}
\hline \multirow{2}{*}{ Indikator } & \multicolumn{1}{|c|}{ Pernyataan } & \multicolumn{5}{c|}{ Skor } & Total & $\begin{array}{c}\text { Rata- } \\
\text { rata } \\
\text { skor }\end{array}$ & Ket \\
\cline { 3 - 7 } & & SS & S & R & TS & STS & \\
\hline $\begin{array}{l}\text { Dorongan } \\
\text { mencapai } \\
\text { tujuan }\end{array}$ & $\begin{array}{l}\text { Gaji yang saya terima } \\
\text { tiap bulan sudah dapat } \\
\text { memenuhi kebutuhan } \\
\text { hidup saya sekeluarga }\end{array}$ & 8 & 13 & 5 & 8 & 1 & 124 & 3,54 & $\mathrm{~B}$ \\
\cline { 2 - 10 } & $\begin{array}{l}\text { Atasan saya } \\
\text { memberikan pujian } \\
\text { atas hasil pekerjaan } \\
\text { yang saya lakukan }\end{array}$ & 6 & 12 & 10 & 7 & 0 & 122 & 3,48 & $\mathrm{~B}$ \\
\hline
\end{tabular}




\begin{tabular}{|c|c|c|c|c|c|c|c|c|c|}
\hline \multirow[t]{2}{*}{$\begin{array}{l}\text { Semangat } \\
\text { Kerja }\end{array}$} & $\begin{array}{l}\text { Perusahaan } \\
\text { memberikan } \\
\text { penghargaan (bonus) } \\
\text { atau promosi jabatan } \\
\text { bagi karyawan yang } \\
\text { berprestasi }\end{array}$ & 7 & 14 & 6 & 8 & 0 & 247 & 3,57 & $\mathrm{~B}$ \\
\hline & $\begin{array}{l}\text { Gaji yang saya sesuai } \\
\text { dengan UMR }\end{array}$ & 3 & 23 & 4 & 4 & 1 & 128 & 3,66 & $\mathrm{~B}$ \\
\hline \multirow[t]{2}{*}{ Inisiatif } & $\begin{array}{l}\text { Saya berinisiatif } \\
\text { mencari penyelesaian } \\
\text { ketika mengalami } \\
\text { kebuntuan kerja }\end{array}$ & 4 & 18 & 6 & 6 & 1 & 123 & 3,51 & $\mathrm{~B}$ \\
\hline & $\begin{array}{l}\text { Saya tidak } \\
\text { membiarkan pekerjaan } \\
\text { menumpuk dimeja } \\
\text { dengan menunda- } \\
\text { nunda pekerjaan }\end{array}$ & 3 & 21 & 6 & 5 & 0 & 127 & 3,62 & $\mathrm{~B}$ \\
\hline \multirow[t]{2}{*}{ Kreatifitas } & $\begin{array}{l}\text { Karyawan diberikan } \\
\text { kebebasan untuk } \\
\text { berkreatifitas dalam } \\
\text { menyelesaikan } \\
\text { pekerjaan }\end{array}$ & 2 & 14 & 10 & 8 & 1 & 113 & 3,22 & KB \\
\hline & $\begin{array}{l}\text { Atasan memberikan } \\
\text { respon positif dan } \\
\text { selalu mendengarkan } \\
\text { masukan \& kritikan } \\
\text { dari karyawan }\end{array}$ & 4 & 12 & 6 & 11 & 2 & 110 & 3,14 & KB \\
\hline \multirow[t]{2}{*}{$\begin{array}{l}\text { Rasa } \\
\text { Tanggung } \\
\text { jawab }\end{array}$} & $\begin{array}{l}\text { Saya berani } \\
\text { mengambil resiko atas } \\
\text { apa yang saya } \\
\text { kerjakan. }\end{array}$ & 4 & 20 & 7 & 3 & 1 & 88 & 2,51 & KB \\
\hline & $\begin{array}{l}\text { Saya memanfaatkan } \\
\text { waktu bekerja dengan } \\
\text { maksimal tidak dengan } \\
\text { mengobrol, chatting, } \\
\text { main game, dll. }\end{array}$ & 5 & 19 & 4 & 7 & 0 & 127 & 3,62 & $\mathrm{~B}$ \\
\hline \multicolumn{2}{|l|}{ Total } & 46 & 166 & 64 & 67 & 7 & 1309 & & \\
\hline \multicolumn{8}{|c|}{ Total Rata-rata Motivasi } & 3,74 & $\mathrm{~B}$ \\
\hline
\end{tabular}

Sumber : Data hasil kuesioner (2018)

Berdasarkan data tabel di atas, rata-rata skor Motivasi sebesar 3,74 masuk pada interval 3,40-4,19 dengan interpretasi Baik yang artinya responden mempunyai persepsi bahwa Motivasi Kerja pada PT. Triview Geospatial Mandiri adalah baik. 
2. Deskripsi Lingkungan Kerja

\begin{tabular}{|c|c|c|c|c|c|c|c|c|c|}
\hline \multirow[t]{2}{*}{ Indikator } & \multirow[t]{2}{*}{ Pernyataan } & \multicolumn{5}{|c|}{ Skor } & \multirow[t]{2}{*}{ Total } & \multirow{2}{*}{$\begin{array}{l}\text { Rata- } \\
\text { rata } \\
\text { skor }\end{array}$} & \multirow[t]{2}{*}{ Ket } \\
\hline & & SS & $\mathbf{S}$ & $\mathbf{R}$ & TS & STS & & & \\
\hline \multirow[t]{2}{*}{$\begin{array}{l}\text { Hubungan } \\
\text { Karyawan }\end{array}$} & $\begin{array}{l}\text { Terjalin hubungan } \\
\text { yang harmonis antar } \\
\text { karyawan, tidak } \\
\text { pernah ada } \\
\text { perselisihan }\end{array}$ & 10 & 14 & 1 & 8 & 2 & 127 & 3,62 & $B$ \\
\hline & $\begin{array}{l}\text { Hubungan antara } \\
\text { karyawan dengan } \\
\text { pimpinan terjalin baik }\end{array}$ & 11 & 14 & 6 & 2 & 2 & 137 & 3,91 & $B$ \\
\hline $\begin{array}{l}\text { Tingkat } \\
\text { Kebisingan }\end{array}$ & $\begin{array}{l}\text { Tingkat kebisingan } \\
\text { yang ada di } \\
\text { lingkungan tempat } \\
\text { saya bekerja tidak } \\
\text { mempengaruhi kinerja } \\
\text { saya }\end{array}$ & 7 & 10 & 6 & 8 & 4 & 117 & 3,34 & $B$ \\
\hline \multirow[t]{2}{*}{$\begin{array}{l}\text { Peraturan } \\
\text { Kerja }\end{array}$} & $\begin{array}{l}\text { Saya mengetahui dan } \\
\text { memahami peraturan } \\
\text { kerja yang berlaku }\end{array}$ & 6 & 14 & 5 & 10 & 0 & 121 & 3,45 & $B$ \\
\hline & $\begin{array}{l}\text { Sanksi hukuman bagi } \\
\text { karyawan yang } \\
\text { melanggar peraturan } \\
\text { memberikan efek jera }\end{array}$ & 5 & 11 & 10 & 9 & 0 & 142 & 4,05 & $B$ \\
\hline \multirow[t]{2}{*}{ Keamanan } & $\begin{array}{l}\text { Keamanan lingkungan } \\
\text { tempat saya berkerja } \\
\text { terjamin keamanannya }\end{array}$ & 8 & 10 & 10 & 6 & 1 & 123 & 3,51 & $B$ \\
\hline & $\begin{array}{l}\text { Fasilitas kerja yang } \\
\text { disediakan oleh } \\
\text { perusahaan sudah } \\
\text { cukup memadai }\end{array}$ & 6 & 8 & 8 & 10 & 3 & 109 & 3,11 & KB \\
\hline Penerangan & $\begin{array}{l}\text { Penerangan di setiap } \\
\text { ruang kerja berjalan } \\
\text { dengan baik }\end{array}$ & 5 & 11 & 6 & 9 & 4 & 134 & 3,83 & B \\
\hline \multirow[t]{2}{*}{$\begin{array}{l}\text { Sirkulasi } \\
\text { Udara }\end{array}$} & $\begin{array}{l}\text { Sirkulasi atau kualitas } \\
\text { udara disekitar tempat } \\
\text { kerja saya sudah baik. }\end{array}$ & 6 & 11 & 4 & 9 & 5 & 139 & 3,97 & B \\
\hline & $\begin{array}{l}\text { Suhu ruangan tempat } \\
\text { saya bekerja } \\
\text { mendukung kinerja } \\
\text { saya. }\end{array}$ & 5 & 11 & 7 & 8 & 4 & 135 & 3,87 & $B$ \\
\hline \multicolumn{2}{|l|}{ Total } & 69 & 114 & 63 & 79 & 25 & 1284 & & \\
\hline \multicolumn{8}{|c|}{ Total Rata-rata Lingkungan Kerja } & 3,66 & B \\
\hline
\end{tabular}

Sumber : Data hasil kuesioner (2018)

Berdasarkan data tabel di atas, rata-rata skor Lingkungan Kerja sebesar 3,66 masuk pada interval 3,40-4,19 dengan interpretasi Baik yang artinya responden mempunyai persepsi bahwa Lingkungan Kerja pada PT. Triview Geospatial Mandiri adalah baik. 
3. Deskripsi Kinerja

\begin{tabular}{|c|c|c|c|c|c|c|c|c|c|}
\hline \multirow[t]{2}{*}{ Indikator } & \multirow[t]{2}{*}{ Pernyataan } & \multicolumn{5}{|c|}{ Skor } & \multirow[t]{2}{*}{ Total } & \multirow{2}{*}{$\begin{array}{l}\text { Rata- } \\
\text { rata } \\
\text { skor }\end{array}$} & \multirow[t]{2}{*}{ Ket } \\
\hline & & SS & $\mathbf{S}$ & $\mathbf{R}$ & TS & STS & & & \\
\hline \multirow[t]{3}{*}{ Kualitas } & $\begin{array}{l}\text { Saya cepat tanggap } \\
\text { terhadap tugas yang } \\
\text { diberikan }\end{array}$ & 7 & 13 & 7 & 7 & 1 & 123 & 3,51 & $B$ \\
\hline & $\begin{array}{l}\text { Saya bersedia } \\
\text { menerima dan } \\
\text { melakukan pekerjaan } \\
\text { diluar jobdesc } \\
\text { pekerjaan saya }\end{array}$ & 4 & 5 & 3 & 13 & 10 & 85 & 2,42 & TB \\
\hline & $\begin{array}{l}\text { Saya bersedia lembur } \\
\text { untuk memenuhi target } \\
\text { perusahaan. }\end{array}$ & 7 & 12 & 3 & 11 & 2 & 116 & 3,31 & $\mathrm{~KB}$ \\
\hline \multirow[t]{3}{*}{ Mutu Kerja } & $\begin{array}{l}\text { Tingkat pencapaian } \\
\text { volume kerja yang saya } \\
\text { hasilkan telah sesuai } \\
\text { dengan SOP \& target } \\
\text { perusahaan }\end{array}$ & 8 & 12 & 14 & 1 & 0 & 132 & 3,77 & $B$ \\
\hline & $\begin{array}{l}\text { Saya melakukan tugas } \\
\text { dengan cermat dan teliti }\end{array}$ & 24 & 9 & 0 & 2 & 0 & 160 & 4,57 & SB \\
\hline & $\begin{array}{l}\text { Saya menyelesaikan } \\
\text { pekerjaaan tepat waktu } \\
\text { sesuai dengan target } \\
\text { yang diberikan }\end{array}$ & 8 & 16 & 8 & 2 & 1 & 133 & 3,8 & $B$ \\
\hline \multirow[t]{2}{*}{ Ketangguhan } & $\begin{array}{l}\text { Saya datang kekantor } \\
\text { tepat waktu sesuai } \\
\text { dengan peraturan } \\
\text { perusahaan }\end{array}$ & 19 & 10 & 1 & 4 & 1 & 147 & 4,20 & SB \\
\hline & $\begin{array}{l}\text { Apabila saya tidak bisa } \\
\text { masuk saya } \\
\text { menginformasikannya } \\
\text { kepada atasan saya }\end{array}$ & 16 & 15 & 2 & 1 & 1 & 149 & 4,25 & SB \\
\hline \multirow[t]{2}{*}{ Sikap } & $\begin{array}{l}\text { Saya dapat menjalin } \\
\text { kerjasama yang baik } \\
\text { dengan teman kerja } \\
\text { dan atasan }\end{array}$ & 7 & 24 & 3 & 1 & 0 & 142 & 4,06 & $B$ \\
\hline & $\begin{array}{l}\text { Saya suka } \\
\text { menyelesaikan } \\
\text { pekerjaan sendiri } \\
\text { dengan cara kerja } \\
\text { sendiri }\end{array}$ & 5 & 12 & 7 & 7 & 4 & 112 & 3,20 & $\mathrm{~KB}$ \\
\hline \multicolumn{2}{|l|}{ Total } & 105 & 128 & 48 & 49 & 20 & 1299 & & \\
\hline \multicolumn{8}{|c|}{ Total Rata-rata Kinerja } & 3,71 & B \\
\hline
\end{tabular}

Sumber : Data hasil kuesioner (2018)

Berdasarkan data tabel di atas, rata-rata skor Kinerja sebesar 3,71 masuk pada interval 3,40-4,19 dengan interpretasi Baik yang artinya responden mempunyai persepsi bahwa Kinerja Karyawan pada PT. Triview Geospatial Mandiri adalah baik. 


\section{Hasil Analisis Data dan Hasil Penelitian}

\section{Uji Validitas dan Uji Reliabilitas}

Hasil uji validitas dengan menggunakn rumus korelasi product moment dan membandingkan dengan $r$ tabel dengan taraf siginfikansi sebesar $5 \%$ maka diperoleh $r$ tabel yaitu 0,3338 sehingga berikut ini hasil intrumen kuesioner no 1 untuk setiap variabel diperoleh nilai:

a. Motivasi, instrument kuesioner no 1 diperoleh nilai $r$ hitung $(0,782)>r_{\text {tabel }}$ $(0,3338)$ sehingga instrument no 1 dikatakan valid.

b. Lingkungan Kerja instrument kuesioner no 1 diperoleh nilai $r$ hitung $(0,670)$ $>r_{\text {tabel }}(0,3338)$ sehingga instrument no 1 dikatakan valid.

c. Kinerja instrument kuesioner no 1 diperoleh nilai $r$ hitung $(0,554)>r_{\text {tabel }}$ $(0,3338)$ sehingga instrument no 1 dikatakan valid.

Setelah dilakukan uji validitas dan seluruh intrumen dinyatakan valid, maka tahap selanjut nya adalah uji reliabilitas dengan alpha cronbach dimana $r$ ca di bandingkan dengan 0,6 pada setiap variabel kuesioner nya:

a. Motivasi, memperoleh nilai $r_{\text {ca }}(0,767)>0,60$ sehingga kuesioner variabel Motivasi dikatakan reliabel.

b. Lingkungan Kerja, memperoleh nilai $r$ ca $(0,780)>0,60$ sehingga kuesioner variabel Lingkungan Kerja dikatakan reliabel

c. Kinerja, memperoleh nilai $r_{\text {ca }}(0,737)>0,60$ sehingga kuesioner variabel KInerja dikatakan reliabel

\section{Uji Asumsi Klasik}

\section{Uji Multikolinearitas}

Pengujian ada tidaknya gejala multikolinieritas dilakukan dengan mempertahankan nilai matriks korelasi yang dihasilkan pada saat pengolahan data serta nilai VIF (Variance Inflation Factor) dan tolerance sebagai berikut:

Hasil Uji Multikolineritas

\begin{tabular}{|c|c|c|c|c|c|c|c|c|}
\hline \multicolumn{9}{|c|}{ Coefficients $^{a}$} \\
\hline \multirow{2}{*}{\multicolumn{2}{|c|}{ Model }} & \multicolumn{2}{|c|}{$\begin{array}{c}\text { Unstandardized } \\
\text { Coefficients }\end{array}$} & \multirow{2}{*}{$\begin{array}{c}\text { Standardized } \\
\text { Coefficients } \\
\text { Beta } \\
\end{array}$} & \multirow[t]{2}{*}{$\mathrm{t}$} & \multirow[t]{2}{*}{ Sig. } & \multicolumn{2}{|c|}{ Collinearity Statistics } \\
\hline & & B & Std. Error & & & & Tolerance & VIF \\
\hline \multirow{3}{*}{1} & (Constant) & 18.737 & 4.330 & & 4.327 & .000 & & \\
\hline & motivasi & .332 & .133 & .394 & 2.504 & .018 & .782 & 1.279 \\
\hline & ling_kerja & .201 & .097 & .324 & 2.060 & .048 & .782 & 1.279 \\
\hline
\end{tabular}

a. Dependent Variable: kinerja

Berdasarkan tabel diatas maka diperoleh nilai tolerance value variabel Motivasi $0,782>0,10$ dan sedangkan VIF nya $1,279<10,00$ lalu nilai tolerance value variabel Lingkungan Kerja diperoleh nilai 0,782 > 0,10 sedangkan VIF nya diperoleh nilai $1,279>0,10$ sehingga data tersebut tidak terjadi multikolinearitas.

\section{Uji Normalitas}

Uji Normalitas bertujuan menguji apakah model regresi, variabel dependen dan independen keduanya memiliki distribusi normal atau tidak. Uji normalitas dapat dilihat dari nilia Asym.sig pada tabel One Sample Kolmogrov Smirnov Test: 


\section{Hasil Uji Normalitas}

One-Sample Kolmogorov-Smirnov Test

\begin{tabular}{|c|c|c|c|c|}
\hline & & motivasi & ling_kerja & kinerja \\
\hline$N$ & & 35 & 35 & 35 \\
\hline \multirow{3}{*}{ Normal Parameters ${ }^{a, b}$} & Mean & 35.06 & 33.51 & 37.11 \\
\hline & Std. Deviation & 6.966 & 9.479 & 5.870 \\
\hline & Absolute & .181 & .119 & .117 \\
\hline \multirow[t]{2}{*}{ Most Extreme Differences } & Positive & .130 & .091 & .101 \\
\hline & Negative & -.181 & -.119 & -.117 \\
\hline Kolmogorov-Smirnov Z & & 1.072 & .702 & .695 \\
\hline Asymp. Sig. (2-tailed) & & .200 & .708 & .720 \\
\hline
\end{tabular}

a. Test distribution is Normal.

b. Calculated from data.

Dari tabel diatas maka diperoleh nilai Asym Sig 2 tailed untuk motivasi $(0,200)$, lingkungan kerja $(0,708)$, kinerja $(0,720)$ dimana semuanya $>0,05$ sehingga data tersebut berdistribusi normal.

\section{Uji Autokorelasi}

Uji Autokorelasi dilakukan untuk mengetahui adakah korelasi variabel yang ada di dalam model prediksi dengan perubahan waktu. Pengujian autokorelasi menggunakan Uji Durbin Watson :

\section{Hasil Uji Autokorelasi}

Model Summary ${ }^{b}$

\begin{tabular}{|l|r|r|r|r|r|}
\hline Model & \multicolumn{1}{|c|}{$\mathrm{R}$} & R Square & \multicolumn{1}{|c|}{$\begin{array}{c}\text { Adjusted R } \\
\text { Square }\end{array}$} & $\begin{array}{l}\text { Std. Error of the } \\
\text { Estimate }\end{array}$ & Durbin-Watson \\
\hline 1 & $.616^{\mathrm{a}}$ & .380 & .341 & 4.764 & 2.073 \\
\hline
\end{tabular}

a. Predictors: (Constant), ling_kerja, motivasi

b. Dependent Variable: kinerja

Tidak terjadi autokorelasi apabila DW $>$ DU dan $(4-D W)>$ DU. Dari tabel diatas Nilai DW 2,073 > DU 1,5838 dan 1,927 > DU 1,5838 artinya tidak terjadi autokorelasi atau bisa dinotasikan juga sebagai berikut: 1,927 > 1,5838 <2,073

\section{Analisis Regresi Linear Berganda}

Hasil Uji Regresi Linier Berganda

\begin{tabular}{|c|c|c|c|c|c|c|}
\hline \multirow{3}{*}{\multicolumn{2}{|c|}{ Model }} & \multicolumn{3}{|c|}{ Coefficients $^{\mathrm{a}}$} & \multirow{3}{*}{$\mathrm{t}$} & \multirow{3}{*}{ Sig. } \\
\hline & & \multicolumn{2}{|c|}{ Unstandardized Coefficients } & \multirow{2}{*}{$\begin{array}{c}\text { Standardized } \\
\text { Coefficients } \\
\text { Beta }\end{array}$} & & \\
\hline & & $\mathrm{B}$ & Std. Error & & & \\
\hline & (Constant) & 18.737 & 4.330 & & 4.327 & .000 \\
\hline 1 & motivasi & .332 & .133 & .394 & 2.504 & .018 \\
\hline & ling_kerja & .201 & .097 & .324 & 2.060 & .048 \\
\hline
\end{tabular}

a. Dependent Variable: kinerja 


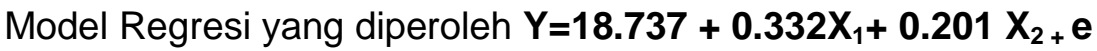

1. Konstanta $(\alpha)$ sebesar 18,737 menyatakan bahwa tanpa variabel Motivasi $\left(\mathrm{X}_{1}\right)$ dan Lingkungan Kerja $\left(\mathrm{X}_{2}\right)$ maka besarnya nilai Kinerja $(\mathrm{Y})$ adalah 13,012

2. Variabel Motivasi $\left(X_{1}\right)$ berpengaruh positif terhadap Kinerja $(Y)$ dengan nilai koefisiensi sebesar 0,332 , yang artinya jika variabel Motivasi $\left(X_{1}\right)$ meningkat satu satuan dengan asumsi variabel Lingkungan Kerja $\left(X_{2}\right)$ tetap, maka Kinerja $(Y)$ akan meningkat sebesar 0,332 , sehingga besar nya pengaruh Motivasi $\left(X_{1}\right)$ terhadap Kinerja $(Y)$ sebesar 33,2\%.

3. Variabel Lingkungan Kerja $\left(\mathrm{X}_{2}\right)$ berpengaruh positif terhadap Kinerja $(\mathrm{Y})$ dengan nilai koefisien sebesar 0,201 yang artinya jika variabel Lingkungan Kerja $\left(X_{2}\right)$ meningkat satu satuan dengan asumsi variabel Motivasi $\left(X_{1}\right)$ tetap, maka Kinerja $(Y)$ akan meningkat sebesar 0,201. Sehingga besar nya pengaruh Lingkungan Kerja $\left(\mathrm{X}_{2}\right)$ terhadap Kinerja $(\mathrm{Y})$ sebesar 20,1\%.

Koefisiensi determinasi $\left(R^{2}\right)$ bertujuan untuk mengetahui seberapa besar kemampuan variabel independen menjelaskan variabel dependen, dapat dilihat pada tabel berikut ini:

\section{Hasil Uji Koefisien Determinasi}

\begin{tabular}{|l|r|r|r|r|}
\hline Model & \multicolumn{2}{|c|}{ Model Summary } \\
\hline 1 & R Square & $\begin{array}{c}\text { Adjusted R } \\
\text { Square }\end{array}$ & Std. Error of the Estimate \\
\hline
\end{tabular}

a. Predictors: (Constant), ling_kerja, motivasi

Hasil uji koefisien determinasi dilihat dari nialai ( $R$ Square) yang diperoleh sebesar 0,380. Hal ini berarti $38 \%$ Kinerja ( $Y$ ) dipengaruhi oleh variabel Motivasi $\left(\mathrm{X}_{1}\right)$ dan Lingkungan Kerja $\left(\mathrm{X}_{2}\right)$ sedangkan sisanya 62\% Kinerja $(\mathrm{Y})$ dipengaruhi oleh variabel-variabel lain yang tidak diteliti, seperti disiplin, kepemimpinan, dan lain-lain.

\section{Uji Hipotesis}

\section{a. Uji T}

Untuk mengethaui terdpaat pengaruh antara Motivasi $\left(X_{1}\right)$ dan Lingkungan Kerja $\left(\mathrm{X}_{2}\right)$ terhadap Kinerja $(\mathrm{Y})$ maka perlu dilakukan uji signifikansi dengan menggunakan uji statistik (uji t) dengan menggunakan taraf siginifikansi sebesar $5 \%(0,05)$ dan derajat kebebasan (dk) korelasi dengan rumus: $\mathrm{dk}=\mathrm{n}-\mathrm{k}-1$, dimana $n$ adalah jumlah responden, dan $k$ adalah jumlah variabel yang diteliti. Dimana t tabel diperoleh: 
Hasil Uji Parsial (uji t)

Coefficients $^{a}$

\begin{tabular}{|c|c|c|c|c|c|c|}
\hline \multirow[t]{2}{*}{ Mode } & & \multicolumn{2}{|c|}{ Unstandardized Coefficients } & \multirow{2}{*}{$\begin{array}{c}\text { Standardized } \\
\text { Coefficients } \\
\text { Beta }\end{array}$} & \multirow[t]{2}{*}{$\mathrm{t}$} & \multirow[t]{2}{*}{ Sig. } \\
\hline & & $B$ & Std. Error & & & \\
\hline \multirow{3}{*}{1} & (Constant) & 18.737 & 4.330 & & 4.327 & .000 \\
\hline & motivasi & .332 & .133 & .394 & 2.504 & .018 \\
\hline & ling_kerja & .201 & .097 & .324 & 2.060 & .048 \\
\hline
\end{tabular}

a. Dependent Variable: kinerja

1) Motivasi $\left(X_{1}\right)$ terhadap Kinerja Karyawan ( $Y$ )

Berdasarkan diatas dapat dilihat bahwa variabel Motivasi $\left(\mathrm{X}_{1}\right)$ diperoleh signifikansi t lebih kecil dari 0,05 $(0,018<0,05)$ dan $\mathrm{t}$ hitung 2,504 $>\mathrm{t}$ tabel sebesar 2,0369 atau berarti $\mathrm{H}_{0}$ ditolak dan $\mathrm{H}_{1}$ diterima, hal ini menunjukan bahwa terdapat pengaruh yang signifikan dari Motivasi $\left(\mathrm{X}_{1}\right)$ terhadap Kinerja (Y)

2) Kualitas Pelayanan $\left(X_{2}\right)$ terhadap Kepuasan Pelanggan ( $Y$ )

Berdasarkan tabel diatas dapat dilihat bahwa variabel Lingkungan Kerja $\left(\mathrm{X}_{2}\right)$ diperoleh signifikansi $t$ lebih kecil dari 0,05 $(0,048<0,05)$ dan $t_{\text {hitung } 2,060>}$ $\mathrm{t}$ tabel sebesar 2,0369 atau berarti $\mathrm{H}_{0}$ ditolak dan $\mathrm{H}_{2}$ diterima, hal ini menunjukan bahwa terdapat pengaruh yang signifikan dari Lingkungan Kerja $\left(\mathrm{X}_{2}\right)$ terhadap Kinerja $(\mathrm{Y})$

b. Uji F

Untuk menguji pengaruh Motivasi $\left(X_{1}\right)$ dan Lingkungan Kerja $\left(X_{2}\right)$ secara bersama-sama (simultan) terhadap Kinerja $(Y)$, dapat digunakan uji statistik $F$ (uji F), dengan menggunakan taraf signifikansi $5 \%(0,05)$.

\section{Hasil Uji Simultan (uji F)}

\begin{tabular}{|rl|r|r|r|r|r|}
\hline \multicolumn{1}{|l|}{ Model } & & Sum of Squares & \multicolumn{1}{c|}{ df } & Mean Square & \multicolumn{1}{c|}{ F } & \multicolumn{1}{c|}{ Sig. } \\
\hline \multirow{2}{*}{1} & Regression & 445.254 & 2 & 222.627 & 9.809 & $.000^{\mathrm{b}}$ \\
& Residual & 726.289 & 32 & 22.697 & & \\
& Total & 1171.543 & 34 & & & \\
\hline
\end{tabular}

a. Dependent Variable: kinerja

b. Predictors: (Constant), ling_kerja, motivasi

Dari hasi uji $F$ dapat diperoelh nilai $f_{\text {hitung }}>f_{\text {tabel }}$ yaitu $9,809>3,29$ dan nilai sig $<0,05$ atau 0,000 < 0,005 Maka, Motivasi $\left(X_{1}\right)$ dan Lingkungan Kerja $\left(X_{2}\right)$ memiliki pengaruh yang signifikan terhadap Kinerja $(\mathrm{Y})$ 


\section{J. Analisis Hasil Penelitian dan Pembahasan}

\section{Motivasi}

a. Dari hasil analisis data maka Motivasi dikatakan baik hal ini dari 35 responden dengan 10 pernyataan dengan rata - rata skor sebesar 3,74 dikategorikan BAIK.

b. Dari hasil uji validitas dan reliabilitas maka instrument kuisioner menunjukan valid seperti instirumen kuesioner no $1(0,782>0,3338)$ dan begitupun hasil uji reliabilitas kuesioner dimana nilai $r_{\text {ca }}(0,767)>0,6$ dinyatakan reliabel.

c. Dari hasil uji analisis regresi berganda maka diperoleh nilai koefisien 0,332, sehingga besarnya pengaruh Motivasi $\left(\mathrm{X}_{1}\right)$ terhadap Kinerja $(\mathrm{Y})$ sebesar $33,2 \%$.

d. Dan hasil uji hipotesis maka diperoleh nilai $\mathrm{t}$ hitung 2,504 $>\mathrm{t}_{\text {tabel }}$ sebesar $2,0369(2,504>2,0369)$ atau berarti $\mathrm{H}_{0}$ ditolak dan $\mathrm{H}_{1}$ diterima, hal ini menunjukan bahwa terdapat pengaruh yang signifikan dari Motivasi $\left(X_{1}\right)$ terhadap Kinerja (Y).

\section{Lingkungan Kerja}

a. Dari hasil analisis data maka Lingkungan Kerja dikatakan baik hal ini dari 35 responden dengan 10 pernyataan dengan rata - rata skor sebesar 3,66 dikategorikan BAIK

b. Dari hasil uji validitas dan reliabilitas maka instrument kuisioner menunjukan valid seperti instirumen kuisioner no $1(0,670>0,3338)$ dan begitupun hasil uji reliabilitas kuisioner dimana nilai $r_{\text {ca }}(0,780)>0,6$ dinyatakan reliabel.

c. Dari hasil uji analisis regresi berganda maka diperoleh nilai koefisien 0,201, sehingga besar nya pengaruh Lingkungan Kerja $\left(X_{2}\right)$ terhadap kepuasan pelanggan (y) sebesar $20,1 \%$.

d. Dan hasil uji hipotesis maka diperoleh nilai $t_{\text {hitung }} 2,060>\mathrm{t}$ tabel sebesar 2,0369 $(2,060>2,0369)$ atau berarti $\mathrm{H}_{0}$ ditolak dan $\mathrm{H}_{2}$ diterima, hal ini menunjukan bahwa terdapat pengaruh yang signifikan dari Lingkungan $\operatorname{Kerja}\left(\mathrm{X}_{2}\right)$ terhadap Kinerja $(\mathrm{Y})$.

\section{Kinerja}

a. Dari hasil analisis data maka Kinerja dikatakan baik hal ini dari 35 responden dengan 10 pernyataan dengan rata - rata skor sebesar 3,71 dikategorikan BAIK

b. Dari hasil uji validitas dan reliabilitas maka instrument kuisioner menunjukan valid seperti instirumen kuisioner no $1(0,554>0,3338)$ dan begitupun hasil uji reliabilitas kuisioner dimana nilai $r_{\text {ca }}(0,737)>0,6$ dinyatakan reliabel.

c. Dari hasil koefisien determinasi dilihat dari nialai ( $R$ Square) yang diperoleh sebesar 0,380. Hal ini berarti $38 \%$ Kinerja $(Y)$ dipengaruhi oleh variabel Motivasi $\left(X_{1}\right)$ dan Lingkungan Kerja $\left(X_{2}\right)$ sedangkan sisanya $62 \%$ Kinerja (Y) dipengaruhi oleh variabel-variabel lain yang tidak diteliti.

d. Dari hasi uji $F$ dapat diperoleh nilai $f_{\text {hitung }}>f_{\text {tabel }}$ yaitu 9,809 $>3,29$ dan nilai sig $<0,05$ atau 0,000 0,005 Maka, Motivasi $\left(X_{1}\right)$ dan Lingkungan Kerja $\left(\mathrm{X}_{2}\right)$ memiliki pengaruh yang signifikan terhadap Kinerja $(\mathrm{Y})$ 
K. Kesimpulan

ISSN (print) : 2598-9545 \& ISSN (online) : 2599-171X

1. Dari hasil analisis regresi linier berganda maka besar nya Motivasi $\left(X_{1}\right)$ terhadap Kinerja $(Y)$ sebesar 33,2\%.

2. Dari hasil analisis regresi linier berganda maka besar nya pengaruh Lingkungan Kerja $\left(X_{2}\right)$ terhadap Kinerja $(Y)$ sebesar $20,1 \%$.

3. Dari hasil koefisien determinasi maka besar nya Motivasi $\left(X_{1}\right)$ dan Lingkungan Kerja $\left(\mathrm{X}_{2}\right)$ terhadap Kinerja $(\mathrm{Y})$ sebesar $38 \%$.

\section{Daftar Pustaka}

Badriyah, Mila. 2017. “Manajemen Sumber Daya Manusia”. Bandung : CV. Pustaka Setia

Hamali, Arif Yusuf. 2017. "Pemahaman Manajemen Sumber Daya Manusia". Yogyakarta : CAPS

Hasibuan, Malayu. 2011. "Manajemen Sumber Daya Manusia”. Jakarta : Bumi Aksara

Hoeloe, lan. 2017. "Unsur-unsur Manajemen”. Retrived August 16, 2018, from http://mastertugasmakalah.blogspot.com/2017/03/unsur-unsur-manajemen.html

Kadarisman, M. 2014. "Manajemen Pengembangan Sumber Daya Manusia". Jakarta : PT. RajaGrafindo Persada

Mangkuprawira, Tb. Sjafri. 2011. “Manajemen Sumber Daya Manusia Strategik”. Bogor : Ghalia Indonesia

Novitasari, Dian. 2017. "Pengaruh Motivasi, Disiplin Kerja dan Kompensasi terhadap Kinerja Karyawan PT. Bank BNI Syariah cabang Suarakarta". Skripsi. Salatiga : Fakultas Ekonomi dan Bisnis Islam IAIN Salatiga

Purnomo, Aan. 2014. “Pengaruh Motivasi Kerja dan Lingkungan Kerja terhadap Kepuasan Kerja Karyawan PT. Hyup Sung Indonesia Purbalingga”. Skripsi. Yogyakarta : Universitas Negeri Yogyakarta

Ridhotullah, Subeki dan Mohammad Jauhar. 2018. "Pengantar Manajemen”. Jakarta : Cerdas Pustaka

Sedarmayanti. 2017. "Tata Kerja dan Produktivitas Kerja". Bandung : CV. Mandar Maju

Sofyan, Soleh. 2017. "Pengaruh Motivasi dan Lingkungan Kerja terhadap Kinerja Guru SMP/MTs Muhammadiyah Cabang Sawangan”. Tesis. Tangerang Selatan

: Program Pasca Sarjana Magister Manajemen Universitas Pamulang.

Sugiyono. 2011. "Metode Penelitian Kuantitatif, Kualitatif dan R\&D". Bandung : Alfabeta

Suhardi. 2018. "Pengantar Manajemen dan Aplikasinya". Yogyakarta : Gava Media

Sunyoto, Danang. 2013. "Manajemen Sumber Daya Manusia". Yogyakarta : CAPS 2017. "Penelitian Sumber Daya Manusia, Teori, Kuesioner, Alat Statistik dan Contoh Riset". Yogyakarta : CAPS

Sutrisno, Edy. 2017. "Manajemen Sumber Daya Manusia”. Jakarta : Karisma Putra Utama

Syahyuti. 2010. "Motivasi Kerja”. Retrieved August 8, 2018, from http://syahyutivariabel.blogspot.com/2010/10/motivasi-kerja.html

Wibowo,2013. "Manajemen Kinerja". Jakarta, Rajawali Pers.

Zainal, Veithial Rivai. 2015. "Manajemen Sumber Daya Manusia untuk Perusahaan: Dari Teori ke Praktik". Jakarta : PT. RajaGrafindo Persada 